\title{
Isolation and Partial Evaluation of a Potential Indigenous Yeast Strain Pichia kudriavzevii from a Traditional Rice Beer-“Gora” Prepared by the Koloi Tribes of Tripura
}

\author{
Sushanta Ghosh1, Surajit De Mandal2, Nandita Nath1, David L. Kaipeng1, Lovely Rahaman1, \\ Senthil Kumar Nachimuthu2, Bipin Kumar Sharma1 ${ }^{*}$ \\ ${ }^{1}$ Department of Microbiology, Tripura University, Suryamaninagar, India \\ ${ }^{2}$ Department of Biotechnology, Mizoram University, Aizawl, India \\ Email: ^bipinkumarsharma77@gmail.com
}

How to cite this paper: Ghosh, S., De Mandal, S., Nath, N., Kaipeng, D.L., Rahaman, L., Nachimuthu, S.K. and Sharma, B.K. (2019) Isolation and Partial Evaluation of a Potential Indigenous Yeast Strain Pichia kudriavzevii from a Traditional Rice Beer- "Gora" Prepared by the Koloi Tribes of Tripura. Advances in Microbiology, 9, 824-841.

https://doi.org/10.4236/aim.2019.99050

Received: December 3, 2018

Accepted: September 9, 2019

Published: September 12, 2019

Copyright $\odot 2019$ by author(s) and Scientific Research Publishing Inc. This work is licensed under the Creative Commons Attribution International License (CC BY 4.0).

http://creativecommons.org/licenses/by/4.0/

\begin{abstract}
As per tradition from hundreds of years the Koloi tribes of Tripura are preparing "Gora"-therice based fermented beer which is very good in taste and aroma applying their traditional indigenous brewing techniques. In this study, an attempt has been made to identify the indigenous yeast which is the main causative agent for fermentation and to investigate its fermentation ability with an industrial Saccharomyces cerevisiaes train. After investigation based on culture dependent phenotypic characteristics like-staining and biochemical characterization, primarily the responsible yeast species was determined as Pichia kudriavzevii and further confirmed followed by $18 \mathrm{~S}$ rRNA ribotyping and the sequences was deposited at Gene bank and NCBI bearing specific accession number. In the comparative analysis, it has been found a significant similarities in all aspects of nutritional and alcohol percentages with the industrial strain in laboratory condition. The alcohol percentage in the rice beer "Gora" measured $6.40 \pm 0.008 \% \mathrm{v} / \mathrm{v}$. The study may be the first scientific investigation of its kind about this indigenous yeast strain isolated from "Gora" of this Indo-Burma biodiversity region and may provide sufficient background and potentiality for promoting these kinds of indigenous alcoholic beverages for small scale commercialization to strengthen the rural livelihood as well as to maintain immaterial cultural heritage.
\end{abstract}

\section{Keywords}

Beer, Yeast, Fermentation, $18 \mathrm{~S}$ rRNA 


\section{Introduction}

Mankind is involved in fermentation as a method of food processing since antiquity. Fermented beverages have always been the integral part of human civilization and established the first signature of human-microbes relationship [1]. It is believed that, the preparation of beer was started in Sumeria before 7000 B.C [2]. Local prepared fermented drinks are always associated with the survival and values of the indigenous people since the beginning of civilization throughout the world [1].

The grace and grandeur of Tripura's beautiful landscape is high lightened by hilly area with two third of its part covered with almost dense forest and also for its rich tribal community, its ethnic, linguistic and cultural diversity. There are 19 major tribal communities in Tripura. They are Tripurri, Reang (Bru), Jamatia, Noatia, Halam, Garo, Mogh, Chakma, Bhil, Orang, Lepcha, Santal, Khasia, Bhutia, Chimal, Uchui, Kuki, Orang and Munda [3]. The Koloi are the sub tribes of the Halam Community constituting about $5.2 \%$ of the total tribal population of Tripura [4]. The term Koloi has been derived from the word "Kului" which means soft hearted. They are very gentle and mild in nature in comparison to the other tribes of Tripura and associated with brewing of traditional alcoholic beverages "Gora" for household consumption [3].

The alcoholic beverages used in different states of North-Eastern India have been assessed and reported by different authors time to time [5] [6] [7] [8] [9]. Each tribal community follows their unique substrates and preparation methods unknowingly using microbes since thousands of years [10]. However, these alcoholic beverages of Tripura have some similarity with the different traditional drinks of world but the basic steps of the fermentation process in different tribes of Tripura are alike [11].

Rice beer has a long historical background and the diversity of traditional preparation can be noticed at household-scale but are mostly region specific, simple and authentic. This study is a continuation of our previous work where we have found a good quality of rice beer produced by the Koloi tribes of Tripura [12]. The present study aims to identify and characterize the yeast strains responsible for fermentation and to evaluate the traditional rice beer for its effectiveness and quality fermentation. The partial qualitative and quantitative evaluation may put forward some new insight with new dimension towards its commercial manufacturing at small industrial scale in future for rural livelihood.

\section{Materials and Methods}

\subsection{Sample Collection and Rice Beer (Gora) Production}

The study was carried out in February to July 2017 and the samples of starter culture, plant species and other ingredients were collected and identified (Figure 1) and the detailed indigenous method of making beer was determined during the field visit. The location of villages was chosen according to the presence of the particular ethnic tribal community. The survey were conducted in the village 

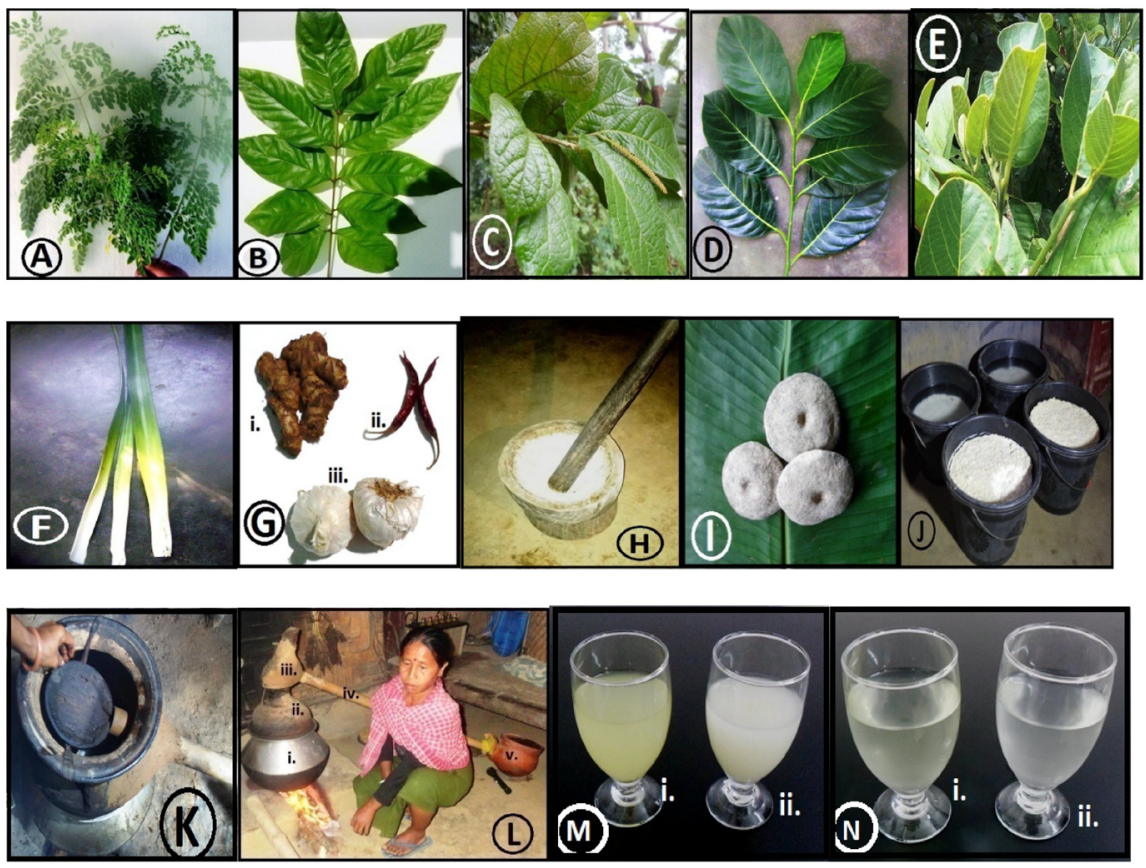

Figure 1. Pictures of different plants, utensils etc used in traditional rice beer preparation. (A) Moringa oleifera Lam. (B) Dysoxylum Blume. (C) Markhamia stipulata (Wall.) Seem. (D) Artocarpus heterophyllus Lam. (E) Litsea monopetala (Roxb.) Pers. (F) Ananas comosus L. (G) (i) Zingiber officinale. (ii) Capsicum annuum. (iii) Allium sativum. (H) The socked rice is crushing in a device locally named "Gylechihat" made up of wood for the starter culture cake preparation. (I) Starter culture cakes called "chuwanbeleb". (J) Starter culture cakes are mixed with the cooled boiled rice and kept for initial fermentation and this is the picture of after two days old initial fermentation. (K) The device acts as a receiver of the drops formed after condensation of the vapor, which are fitted in the device called "batibakhrak". (L) The whole arrangements for making the traditional rice beer in totally called "baittal". (L-i) After the due course of fermentation the whole fermented product is placed in this cooking pot called "bati-deck" over heat for steam generation. (L-ii) The device called "batisabasa" acts as a condenser made up of clay. (L-iii) The device called "bati-deck" used as a water circulator for condensation of the vapor. The water are changed time to time to keep cool the device. (L-iv) The device made up of bamboo used as a collection pipe for the distilled beer. (L-v) The device called "patini" made up of clay used as a collection pot of the distillate. (M) The un-distilled final product of rice beer "Gora" (i) made by the strain NN/SG II. And (ii) made by the strain S249. (N) The distilled final product of rice beer "Chuwak" (i) made by the strain NN/SG II. And (ii) made by the strain $\mathrm{S} 249$.

Tuisindrai (Latitude-23 $82^{\prime} 42.99^{\prime \prime} \mathrm{N}$ and Longitude-91 $61^{\circ} 97.73^{\prime \prime E}$ ). under Tusindrai gram panchayat, Teliamura sub-division, Khowai district, State-Tripura, India (Figure 2).

The samples of starter culture, plant species and other ingredients were collected and the detailed indigenous method of making beer was documented during the field visit (Figure 1). The process of rice beer making involves whole rice grains which is cleaned and soaked in water for a few hours followed by cooking and is spread over banana leaf or a mat for $1-2$ hours for cooling. The starter culture cake "Chuwanchwla" is used as inoculum for this preparation and 


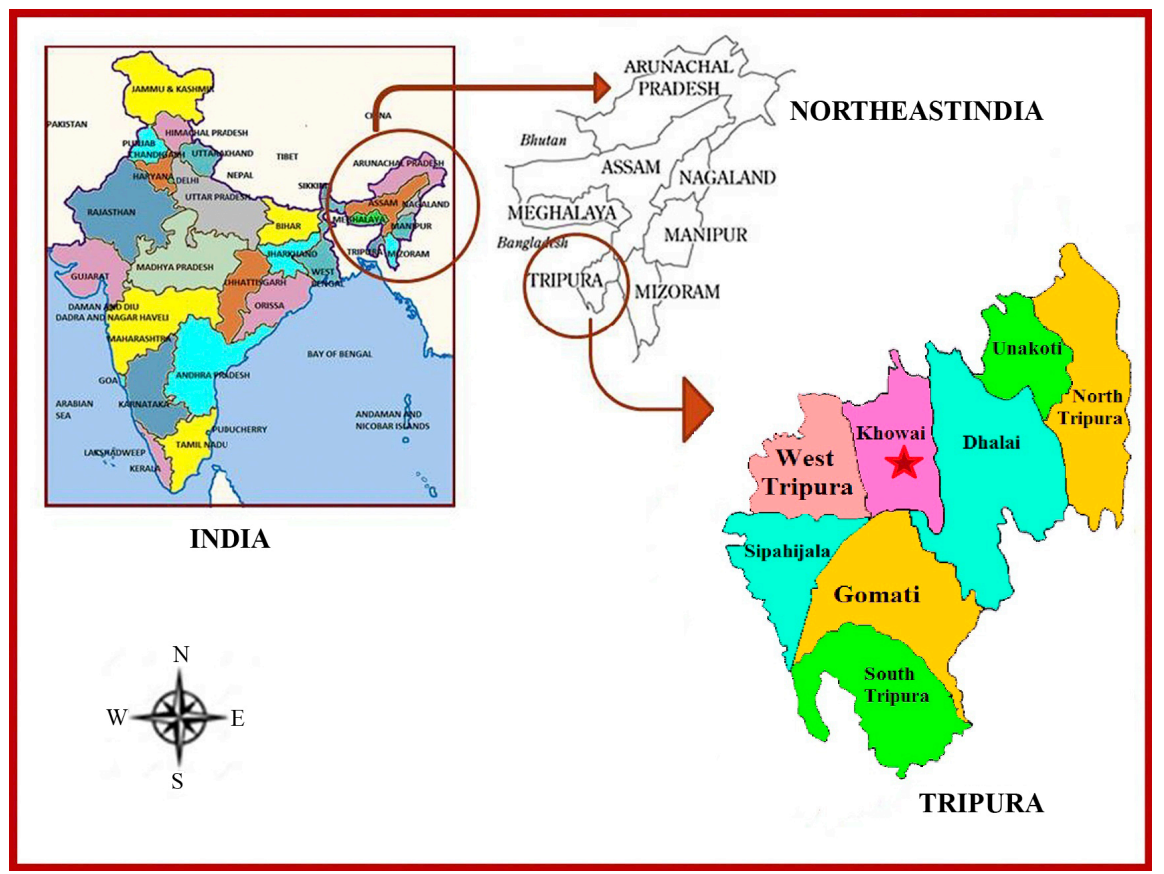

Figure 2. Location of the Tripura state and the sampling sites of the selected Koloi tribe of ruralarea from village—Tuisindrai (Latitude-23 $82^{\prime} 42.99^{\prime \prime} \mathrm{N}$ and Longitude-91 $61^{\circ} 97.73^{\prime \prime} \mathrm{E}$ ) under Tusindrai gram panchayet, Teliamurasub-division, Khowai district, State-Tripura, India.

kept for natural fermentation. After cooling an appropriate amount of starter culture is mixed with cold cooked rice (approx50 gm in $1 \mathrm{~kg}$ ). Then the mixture is placed in a container (batikasla) and covered with banana leaf so that minimum vapor can escape out of the container (Figure $1(\mathrm{~J})$ )). After that the container is covered with clean cloth and kept for $3-4$ days for primary fermentation. After 2 - 3 days some water is added and kept again for 3 - 4 days for secondary fermentation. After secondary fermentation, the turbid milky watery extract is filtered and consumed as un-distilled rice beer (Gora). For preparing distilled rice beer, the mixture is heated and the vapor is collected in another container (batibakhrak) placed on the top of the container (Figure 1(L-ii)) and the vapour from batibakhrak is allowed to pass through a bamboo (batisabchaw) in another container containing water (patini) to collect the distilled one which is called "Chuwak" and this distilled beer can be kept for a week for later consumption (Figure 1). However in the laboratory, the same procedure was followed to make Gora and Chuwak under aseptic conditions followed by primary and secondary fermentation. During the fermentation samples were been drawn in regular intervals for analysis.

\subsection{Collection of the Industrial Strain}

The industrial brew yeast $S$. Cerevisiae (MTCC 249) was collected from Kalyani University, Kalyani, West Bengal, India. The rice beer was made in the laboratory in the same manner using the industrial yeast instead of the traditional rice 
beer starter cake used by the Koloi tribe. During the fermentation, samples were also analysed in regular intervals side by side.

\subsection{Enumeration and Isolation of Yeast}

\subsubsection{Microbiological Analysis of Gora}

The samples of fermented Gora-slury were taken after $72 \mathrm{hr}$ of fermentation in laboratory condition. One gram sample was serially diluted from $10^{-1}-10^{-7}$ using $1 \mathrm{ml}$ physiological saline water and $0.1 \mathrm{ml}$ of sample were spread over YPD Agar (Himedia) enriched with antibiotic ( $5 \mu \mathrm{g}$ chloramphenicol $/ \mathrm{ml}$ ) as done by Dewan and Tamangin 2007 [13]. Then the plates were incubated at $30^{\circ} \mathrm{C}$ for 3 5 days. Based on colony characteristics and macroscopic observations, the colonies were randomly picked and were morphologically characterized. We found single type of yeast strain. Further we prepared pure cultured and preserved in YEPG broth with $20 \%$ glycerol at $-20^{\circ} \mathrm{C}$ for further investigation.

\subsubsection{Phenotypic and Genotypic Characterization of Isolate}

The isolated strain were grown on YM agar and 5\% malt extract agar and was examined by vegetative cell, ascospore, colony morphologies and pseudohyphae detection by Calmau plate culture method with corn meal agar and by staining as mentioned in The Yeast: a taxonomic study, 4th ed [2]. Utilization of carbon sources like Glucose, Sucrose, Maltose, Galactose, D-xylose, D-Xylose, L-rhamnose, 4\% Raffinose, Citrate, D-mannitol, Strach, Glycerol, Ethanol, methanol, n-acetylglucoseamine and nitrogen sources (nitrate, nitrite, L-lysine, D-glucoseamine) were determined by replica plate method. Briefly, plates containing all the carbon and nitrogen source in yeast carbon base (Himedia) and yeast nitrogen base (Himedia) were inoculated with the isolates along with the negative control plates (without carbon or nitrogen sources) and kept in the incubator at $30^{\circ} \mathrm{C}$ for $48-72 \mathrm{hr}$. The result was determined by comparing the negative control plates [14].

To determine the fermentation capability of the isolates on different sugar sources (glucose, sucrose, fructose, maltose, lactose, galactose, trehalose, xylose, $4 \%$ of raffinose and L-malic acid) were done by following the method as mentioned by Kurtzman et al. (2011) [14]. Here the fresh pure yeast cells were suspended with $2 \%$ different sugar solution containing phenol red indicator and the Durham tubes were inserted in inverted position aseptically in to the tube and kept for 22 - 25 days at $30^{\circ} \mathrm{C}$. The fermentation ability was determined by inspecting the accumulation of gas into the Durham tubes and colour change of the media [14].

Other physiological characteristics like growth physiology in different temperature, $\mathrm{pH}$, starch hydrolysis, urea hydrolysis etc were studied following to the methods of Kurtzman and Fell (1998) [2].

\subsection{DNA Isolation and Amplification of ITS Region}

Total genomic DNA was extracted from the yeast cells according to Cenis (1992) 
with minor modification [15]. The internal transcribed spacer (ITS) region was amplified by polymerase chain reaction (PCR) using universal primers ITS1 (5'-TCCGTAGGTGAACCTGCGG-3') and ITS4

(5'-TCCTCCGCTTATTGATATGC-3') [16]. The amplification mix contained $40 \mathrm{mM}$ dNTPs (NEB, MA, USA); 5X Phusion HF reaction buffers (NEB, MA, USA); 2 U/ $\mu$ l F-540 Special Phusion HS DNA Polymerase (NEB, MA, USA); and $5 \mathrm{ng}$ DNA and Milli-Q water to make up $30 \mu \mathrm{l}$ total volume. The PCR running conditions consisted of an initial $98^{\circ} \mathrm{C}$ for $30 \mathrm{~s}$ followed by 30 cycles of $98^{\circ} \mathrm{C}$ for $10 \mathrm{~s}, 72^{\circ} \mathrm{C}$ for $30 \mathrm{~s}$, and a final extension at $72^{\circ} \mathrm{C}$ for $5 \mathrm{~s}$. Successful amplification was confirmed by agarose gel electrophoresis and sequenced with Big Dye (3.1) terminator protocol using ABI 3500 Genetic Analyzer (Applied Biosystem, USA) in the Department of Biotechnology, Mizoram University.

\subsection{Alignment and Phylogenetic Analysis}

The ITS gene sequences of the isolates were searched for their homologue sequences in public domain databases. Identification to the species level was determined with a sequence similarity of $\geq 97 \%$ with that of a prototype strain sequence in Gen Bank using Basic Local Alignment Search Tool (BLAST) [17]. Phylogenetic trees were constructed with MEGA version 6.0 using a neighbor-joining algorithm bootstrap analyses for 1000 replicates where the evolutionary distances were computed using the Tamura 3-parameter method and are in the units of the number of base substitutions per site [18] [19] [20] [21].

\subsection{Qualitative Analysis of the Rice Beer}

\subsubsection{Preparation of Starter Culture in Laboratory Condition}

First both the isolated and industrial yeast strain were inoculated in 1 lt. Erlenmeyer flasks containing $500 \mathrm{ml}$ YEPD broth (Himedia) and Kept in BOD rotary shaker for $3-5$ days at $30^{\circ} \mathrm{C}$. The cell count was determined by haemocytometer, and the cells were harvested by centrifugation and washed with PBS twice. After that, maintaining the aseptic condition rice is soaked and grinded into fine paste. Other associated different parts of the plants listed (Table 1) are dried and finely powdered and sieved. Then all the ingredients along with the both yeast strain were mixed separately with distilled water to make the dough. From the dough cake was made taking a handful of the mixture of 50 to 70 grams for each. Finally the cakes are dried in the oven (Figure 1(I)) and kept for future use.

\subsubsection{Rice Beer Production by the Isolated and Industrial Yeast Strain}

To determine the alcohol production capability and qualitative analysis beer production was done in the laboratory by those yeast cakes made of by the isolated and industrial yeast strains separately following the same method carried out in laboratory condition previously using same substrate (Figure 3).

\subsubsection{Analysis of Physicochemical Properties of the Rice Beer}

Physicochemical properties such as state, color, taste and opacity were executed 
Table 1. Plants, plant parts, and other ingredients used by Koloi tribes for the preparation of starter culture cake for rice beer.

\begin{tabular}{|c|c|c|c|c|}
\hline Local names and common names & Scientific name & Family & Parts used & Other ingredients \\
\hline Sajnabukur (Drumstick) & Moringa oleifera Lam. & Moringaceae & Bark & \multirow{9}{*}{$\begin{array}{c}\text { Atop mairom (Rice), } \\
\text { Rishum (Garlic), } \\
\text { Mosokwthang } \\
\text { (Green Chilli) }\end{array}$} \\
\hline $\begin{array}{c}\text { Chuwanthwichwla } \\
\text { bukur and bwlai (Rosewood) }\end{array}$ & Dysoxylum Blume. & Meliaceae & Bark and leaves & \\
\hline Chuwanbwlai (Khae) & Markhamia stipulata (Wall.) Seem. & Bignoniaceae & Leaf & \\
\hline Theipungbwlai (Jackfruit) & Artocarpus heterophyllus Lam. & Moraceae & Leaf & \\
\hline Barmajalbwlai (Meda) & $\begin{array}{c}\text { Litsea monopetala (Roxb.) Pers. } \\
\text { Ananas comosus } \mathrm{L}\end{array}$ & Bromeliaceae & Leaf & \\
\hline Kurukbwlai (sugarcane) & Saccharum officinarum $\mathrm{L}$. & Poaceae & Leaf & \\
\hline Moskathai (Red chilli) & Capsicum annuum & Solanaceae & Fruit & \\
\hline Rishum (Garlic) & Allium sativum & Amaryllidaceae & Clove & \\
\hline Hasin (Ginger) & Zingiber officinale & Zingibaraceae & Rhizome & \\
\hline
\end{tabular}

The methodology of preparation of 'Gora' is consists of two parts includingthe starter culture cake (Chuwanchwla)preparation and brewing.

Preparation of the starter culture cake.

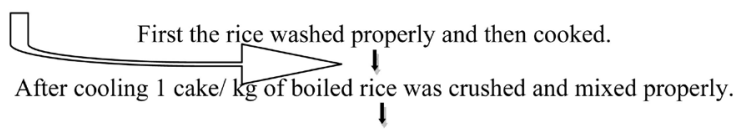

The mixture is then placed in a container and externally covered with banana leaf and kept for 12 days for fermentation.

Then after two dayssome water is mixed with the fermented rice and again kept for 1-2 days further fermentation.

After that a yellowish white color raw beer locally known as Gora is extracted from the mixture.

After that again water is added and allowed to remain for one more night. $\downarrow$

Then the whole mixture is kept in oven at low heat for distillation to get the raw beer called 'Chuwak' in traditionally designed apparatus.

Figure 3. Flow chart of the traditional rice beer preparation by the "Koloi" tribe.

by simple observation. $\mathrm{pH}$ reading of the samples were taken by standard $\mathrm{pH}$ meter of Eutech instruments equipped with glass electrode followed by [12].

\subsubsection{Analysis of Biochemical Properties of the Rice Beer}

Preliminary test of the rice beer were done to see the presence of carbohydrates, polysaccharides, reducing sugars and proteins in the samples. Molisch's test was done with Molisch's reagent to see the presence of carbohydrates. Iodine test was done to see the presence of polysaccharides. Benedict's test was done using Benedict's reagent to see the presence of reducing sugars and Biuret's test was done with Biuret reagent to see the presence of proteins in the sample [22].

\subsubsection{Quantitative analysis for Rice Beer}

The percentage of moisture content was determined by heating $1 \mathrm{gm}$ of the sample at $135^{\circ} \mathrm{C}$ for 2 hours as done by JP Tamang and others [9]. The amount of total carbohydrate in the sample was determined by phenol-sulphuric acid 
assay method using glucose (Stock concentration $2 \mathrm{mg} / \mathrm{ml}$ ) as standard [23]. The amount of reducing sugar was estimated by the standard biochemical method using 3,5-dinitrosalicylic acid (DNS) reagent and taking glucose (Stock concentration $1 \mathrm{mg} / \mathrm{ml}$ ) as standard [22]. The non-reducing sugar was calculated by subtracting the amount of reducing sugar from the amount of total carbohydrate in the sample [22]. The total protein content was estimated by the standard Biuret assay method using Bovine serum albumin (BSA) of $10 \mathrm{mg} / \mathrm{ml}$ stock as standard [24]. Total acidity and volatile acidity was determined by titration of the samples against sodium hydroxide solution using phenolphthalein as indicator and expressed as grams of tartaric acid present per $100 \mathrm{ml}$ of the samples and grams of acetic acid present per $100 \mathrm{ml}$ of the samples [25]. Alcohol percentage of the non-distilled rice beer was determined by titration of the samples against sodium thiosulphate solution using dichromate oxidation method and expressed in percentage volume by volume [26]. The rice beer was then subjected to distillation and the distillate was collected. The alcohol percentage of the distillate was determined by the titration method [26].

\subsection{Sensory Evaluation}

The sensory evolution was carried out by a food technology scholar panel of 10 members. The final product was evaluated for the following attributes: aroma, appearance, flavor, purity of taste, mouth-feel, gustatory sensations (tingling, bitterness etc.) according to the Standard ISO 8586:2012 with slight modification [27]. Both the beer samples were kept at $4^{\circ} \mathrm{C}-8^{\circ} \mathrm{C}$ for analysis. The rice beer samples in glass cups were given to the panelist in a single cabin with partition for evolution for different sensory characteristics. The samples were evaluated in random order and every time after testing panelist rinsed their mouth thoroughly between samples with $10 \mathrm{~min}$ of intervals. Both the samples were assessed three times. The grading system of the beer samples were on a $10 \mathrm{~cm}$ unstructured line scale from 0 to 10 for the testers [28].

\section{Result and Discussions}

The objective of this work was to identify the fermentation procedure adapted by the ethnic community, the yeast species responsible for rice beer fermentation and a comparative study against an industrial strain for its qualitative aspects.

The diversity of traditional preparation can be noticed at household-scale follow their own unique substrates and preparation methods. It has been found that, the flavor and taste of the rice beer is different in different communities of tribes in Tripura [12]. However, alcoholic beverages of Tripura have some similarity with the different traditional drinks of world like shaosingiju and laochao of China; tapuy, brem, bali and tape-ketan of Indonesia; khaomak of Thailand; tapaipulul of Malaysia; chongju and takju of Korea; sake of Japan [11]. The indigenous alcoholic beverages of North-East India have been evaluated and re- 
ported by different authors time to time [5] [6]. Some workers have been isolated verity of yeast strains like Saccharomyces cerevisiae, Hanseniaspora sp., Candida sp., Kloeckera sp., Pichia sp. etc. isolated from rice beer of North Eastern India [7] [8].

The Koloi tribe uses different types of plant and rice verities to impart taste and flavour to the rice beer enlisted in (Table 1). The different plants they use like Moringa olifera Lam. is used in treating jaundice and common cold [29], Ananas comosus L. possess antioxidant activity [30], Markhamia stipulata (Wall.) Seem used in treating nervous disease [31], Artocarpus heterophyllus Lam. is used in treating of skin disease and as an anti-helminthic plant [32], Saccharum officinarum L. is used to get relief in constipation [32], Litseamonopetala (Roxb.) Pers. has antioxidant properties and is used for preventing degenerative diseases including inflammation [33]. The use of different plant verities of medicinal importance plays a major role by contributing different types of phytochemicals, influence secretion of secondary metabolites from the microbes and helps in maintaining complementary and overlapping mechanisms of oxidative agents, stimulating the immune system, regulation of gene expression in cell proliferation, and apoptosis etc [30].

\subsection{Characterization of the Isolated Yeast Strain from Gora}

Interestingly after several sequential cultivations of samples we obtained only a single type of yeast strain from the sample of "Gora". Morphological examination for cultural characteristics revealed a butyrous, white and light cream colour, round to elongate shaped with small lobes, smooth texture, flat elevation, entire marginal and transparent opacity in nature. In YPD broth culture pellicles was formed. Ascospore, pseudohyphae and budding stage was observed under the microscope and the results are illustrated in (Table 2).

Table 2. Microscopical and physiological properties of the isolated yeast strain NN/SGII (“+” = positive, “-" = negative, “++" = good, "S" = strong, "W" = weak).

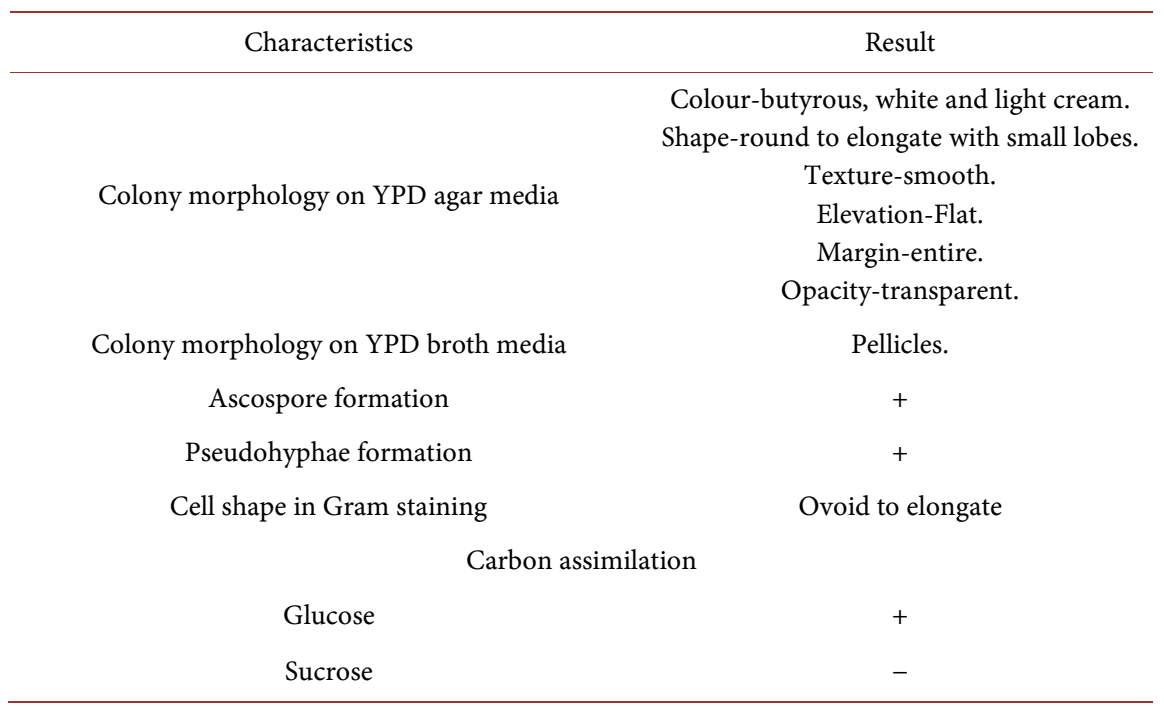




\section{Continued}

\section{Moltose \\ Galactose \\ D-ribose \\ D-xylose}

L-rhamnose

4\%Raffinose

Citrate

D-mannitol

Strach

Glycerol

Ethanol

Methanol

Nitrogen assimilation
L-lysine
Nitrate
Nitrite

D-glucoseamine

Fermentation of carbohydrate

\begin{tabular}{|c|c|}
\hline Glucose & + \\
\hline Sucrose & - \\
\hline Fructose & + \\
\hline Maltose & - \\
\hline Lactose & - \\
\hline Galactose & - \\
\hline Trehalose & - \\
\hline Xylose & - \\
\hline $4 \%$ Raffinose & - \\
\hline L-malic acid & + \\
\hline Xylose & - \\
\hline \multicolumn{2}{|c|}{ Growth in different temperature } \\
\hline $25^{\circ} \mathrm{C}$ & $\mathrm{W}$ \\
\hline $30^{\circ} \mathrm{C}$ & $\mathrm{S}$ \\
\hline $37^{\circ} \mathrm{C}$ & ++ \\
\hline $40^{\circ} \mathrm{C}$ & $\mathrm{W}$ \\
\hline \multicolumn{2}{|c|}{ Growth in different $\mathrm{pH}$} \\
\hline 6 & $\mathrm{~W}$ \\
\hline 6.5 & $\mathrm{~S}$ \\
\hline 7 & + \\
\hline 7.5 & $\mathrm{~W}$ \\
\hline
\end{tabular}

Weak

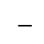

$-$

$-$

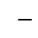

$-$

Weak

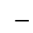

$-$

$+$

$+$

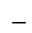

$+$

$-$

$-$

$-$

$-$

$-$

$-$$$
\text { (1) }
$$

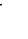$$
-
$$ 
The isolated yeast strain holds a high assimilating activity against glucose, glycerol and methanol but weak in maltose and citrate metabolism. Within the nitrogenous compound only L-lysine was found to be assimilated. In case of sugar fermentation the isolate was able to ferment glucose, fructose and mallic acid only. The capability to grow in different temperature, $\mathrm{pH}$ was determined comparing the measurement of growth in the media at $\mathrm{OD}_{600}$. The other physiological characteristics-growth in different temperature, $\mathrm{pH}$, Urea hydrolysis and starch hydrolysis are given (Table 2). All these preliminary morphological and physiochemical analysis showed similar characteristics with Pichia kudriavzevii [14]. The blast search of the ITS region of the isolated strain showed 99\% $100 \%$ similarity with the yeast strain Pichia kudriavzevii isolated from different parts of the worlds. All the conventional, molecular and phylogenetic analysis reviled that the isolated strain was Pichia kudriavzevii (Figure 4) [34] [35].

\subsection{Characteristics of Rice Beer Made in Laboratory Condition with the Isolated and Industrial Yeast Strain}

The preliminary qualitative physical properties like taste, state, opacity of both the rice beer are mentioned in (Table 3). A trend of gradual decrease in the $\mathrm{pH}$ from initial range $5.5 \pm 0.004$ to $3.55 \pm 0.002$ and $5.5 \pm 0.004$ to $3.53 \pm 0.003$ during 6 - 7 days of fermentation has been observed using the indigenous and commercial yeast strain respectively. The degree of acidity $(\mathrm{pH})$ of the rice beer plays a significant role in its stability during ageing as well as maintains its freshness, taste and flavor. The low $\mathrm{pH}$ or high acidity comes from the different degree of utilization of the carbon substrates (rice and plant varieties) used during fermentation by the different tribes. During the growth the yeast cell consume nitrogen source from the substrate and release hydrogen ions continuously leading to decrease in the $\mathrm{pH}$ of the solution [36]. This low $\mathrm{pH}$ ultimately helps in eliminating enteric pathogens, coliforms and spoilage organisms and enhances the growth of yeast cells in the process. The total acidity of the final product measured $2.20 \pm 0.035$ and $2.53 \pm 0.059$ for both the beers respectively. The volatile acidity of Gora also followed the same trend and found $1.34 \pm 0.083$ and $1.73 \pm 0.017$ respectively as fermentation progressed. As reported some yeast

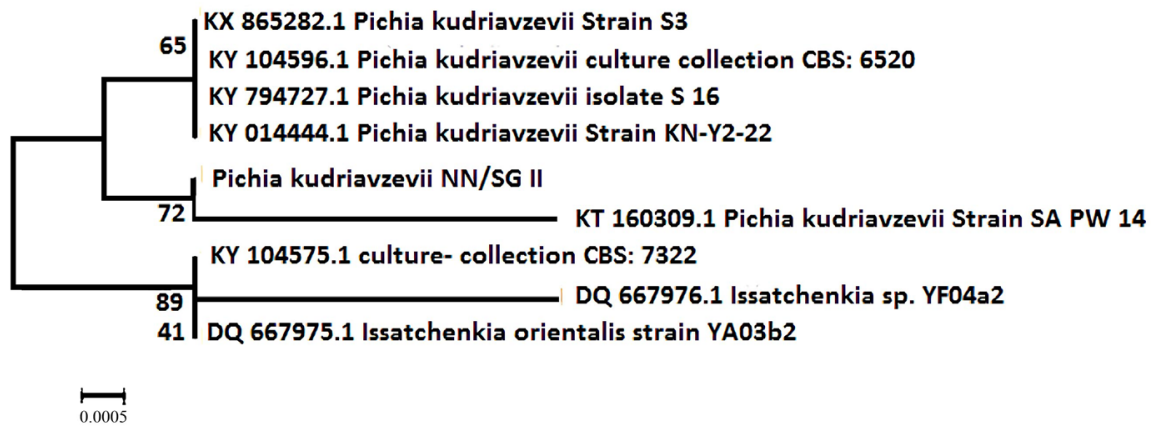

Figure 4. Phylogenetic relationship between Pichia kudriavzevii strain NN/SG 11 and other sequences of published strains. Numbers above branches are bootstrap values, shown greater than $50 \%$. 
Table 3. Qualitative physical properties of the rice beer (NN/SG II-“Gora”, S249-beer made by the industrial strain).

\begin{tabular}{ccc}
\hline \multirow{2}{*}{ Parameters } & \multicolumn{2}{c}{ Observation } \\
\cline { 2 - 3 } & NN/SG II & S249 \\
\hline State & Liquid & Liquid \\
Color & Pale yellow & Pale yellow \\
Taste & Sour, tongue sensitizing & Pungent, tongue sensitizing \\
Opacity & Opaque & Opaque \\
\hline
\end{tabular}

also produce acid in alcohol fermentation and this acidity in beer plays a significant role in ageing of rice beer enhancing the flavor of the product [37]. The moisture content was measured after fermentation for the both rice beer was found to be $80.6 \pm 0.001$ and $78.5 \pm 0.008$ respectively, moisture content directly affects the food quality, microbial stability, and chemical aspects of the beer. It is also a pre requisite in food processing industries for operating with legal bindings and proper labeling of the product for marketing [38]. The total carbohydrates were analyzed during fermentation at an interval of 3 days from their initial stage shows a rapid decrease of carbohydrate $(\mathrm{mg} / \mathrm{ml})$ content from $5.2 \pm$ 0.004 to $0.573 \pm 0.053$ and $0.56 \pm 0.101$ to $5.4 \pm 0.013$ for rice beer produced by the local and the industrial strain respectively. The rice varieties, different plant species and the microbial load of starter culture may be associated with the degree of carbohydrate decomposition in rice beer. The microbes present in the starter culture utilize the carbohydrate as substrates and plays an important role in their metabolism by partial decomposition of carbohydrate and this phenomenon can be beneficial for fermentation yields [39]. After a due course of time of fermentation the sugars starts rapidly metabolize in to acids, ethanol, carbon dioxide, biomass etc. required for the growth of microorganisms [40]. The reducing sugar was found to $1.19 \pm 0.999 \mathrm{mg} / \mathrm{ml}$ and $1.04 \pm 0.999 \mathrm{mg} / \mathrm{ml}$ whereas the non-reducing sugar was $0.77 \pm 0.014 \mathrm{mg} / \mathrm{ml}$ and $1.04 \pm 0.010 \mathrm{mg} / \mathrm{ml} \mathrm{respec-}$ tively of the final product after 7 days in both the cases. The increase of reducing sugar may be due to hydrolysis of starch and oligosaccharides and the activity of amylases present in the cereal grains and the amylase is responsible for initial phases of fermentation by the microorganism [41]. In fermentation sugar catabolism is an oxidative process reduces the production of reduced pyridine nucleotides after that re-oxidized for further biological process to continue under anaerobic condition. In yeast, the NADH is regenerated by the reduction of pyruvic acid to ethanol [42]. Initially the reducing sugar level increases but ultimately it decreases with the time of ageing. This might be due to the microbes present in rice beer which utilize the reducing sugar for the production of alcohol and energy [22]. The protein content of the rice beer was found increased from $5.5 \pm 0.041$ to $11.96 \pm 0.001$ and $5.6 \pm 0.034$ to $11.63 \pm 0.002$ respectively in both the cases as shown in the Table 4 . The protein level is directly proportional 
Table 4. Quantitative biochemical properties of rice beer produced by indigenous and industrial strain (NN/SG II- "Gora", S249-beer made by the industrial strain, "ND"not done).

\begin{tabular}{ccccc}
\hline \multirow{2}{*}{ Parameter } & \multicolumn{2}{c}{ NN/SG II } & \multicolumn{2}{c}{ S249 } \\
\cline { 2 - 5 } & Initial & Final & Initial & Final \\
\hline Ph & $5.5 \pm 0.004$ & $3.55 \pm 0.002$ & $5.5 \pm 0.004$ & $3.53 \pm 0.003$ \\
Moisture $(\%)$ & ND & $80.6 \pm 0.001$ & ND & $78.5 \pm 0.008$ \\
Carbohydrate $(\mathrm{mg} / \mathrm{ml})$ & $5.2 \pm 0.004$ & $0.573 \pm 0.053$ & $5.4 \pm 0.013$ & $0.56 \pm 0.101$ \\
Reducing Sugar $(\mathrm{mg} / \mathrm{ml})$ & $0.36 \pm 0.002$ & $1.19 \pm 0.999$ & $0.034 \pm 0.001$ & $1.04 \pm 0.999$ \\
Non-reducing Sugar $(\mathrm{mg} / \mathrm{ml})$ & ND & $1.04 \pm 0.010$ & ND & $0.77 \pm 0.014$ \\
Protein $(\mathrm{mg} / \mathrm{ml})$ & $5.5 \pm 0.041$ & $11.96 \pm 0.001$ & $5.6 \pm 0.034$ & $11.63 \pm 0.002$ \\
Total acidity $(\mathrm{gm} / 100 \mathrm{ml})$ & ND & $2.20 \pm 0.035$ & ND & $2.53 \pm 0.059$ \\
Volatile acidity $(\mathrm{gm} / 100 \mathrm{ml})$ & ND & $1.34 \pm 0.083$ & ND & $1.73 \pm 0.017$ \\
Alcohol percentage $(\% \mathrm{v} / \mathrm{v})$ & $\mathrm{ND}$ & $6.40 \pm 0.008$ & ND & $6.30 \pm 0.007$ \\
Alcohol percentage of distillate $(\% \mathrm{v} / \mathrm{v})$ & $\mathrm{ND}$ & $31.46 \pm 0.014$ & $\mathrm{ND}$ & $33.20 \pm 0.028$ \\
\hline
\end{tabular}

to the microbial biomass and if the microbial biomass is high, fermentation will be more and the alcohol content will be more [22]. Higher the protein content, beneficial will be the product, resulting adequate protein intake by the consumers. Total alcohol content was measured for the final product and was found 6.40 $\pm 0.008 \mathrm{v} / \mathrm{v}$ for Gora and $6.30 \pm 0.007 \mathrm{v} / \mathrm{v}$ for the beer prepared using the industrial strain. The distilled alcohol of "Chuwak" was found to $31.46 \pm 0.014 \mathrm{v} / \mathrm{v}$ and $33.20 \pm 0.028 \mathrm{v} / \mathrm{v}$ for beer prepared using both the strain respectively. The studied samples showed significant $(p<0.05)$ results for different parameters (Table 4). These findings show and provide sufficient hope and scope for the fermented rice beer to enhancement its quality, nutrient enrichment, increasing self-life and product stability through ageing. Further careful exploration and study is required and will be promising for its large scale production and commercialization.

\subsection{Sensory Analysis of Rice Beer}

The sensory analysis is to evaluate food products which includes evoking, measuring, analyzing and interpreting by senses of sight, smell, taste, touch and hearing by the individuals. In this study the ten scale grading system (between 0 - 10) was used to evaluate the beer based on their individual sensory feelings of the candidates participated. Results of five tested parameters (aroma, appearance, flavor, mouth-feel and overall impression) were shown in (Table 5). The fragrance or aroma of the beer depends on the yeast strain, substrate, hops or other plant parts and ingredients used during fermentation as well as its by-products [43]. Present study showed that the scores of aroma in both the beer samples were nearly equal (Figure 5). Appearance of both the beer ware also results in similar score (Table 5). Gora possess more foam stability then the industrial 
Table 5. Sensory analyses of the rice beer of both Gora and industrial strain shows the mean values of parameters evaluated in sensory analysis (NN/SG II-“Gora", S249-beer made by the industrial strain).

\begin{tabular}{lccccccccccc}
\hline & \multicolumn{3}{c}{ Aroma } & \multicolumn{3}{c}{ Appearance } & \multicolumn{3}{c}{ Flavor } & \multicolumn{3}{c}{ Mouth-feel } & \multicolumn{2}{c}{ Overall impression } \\
\cline { 2 - 11 } & NN/SG II & S249 & NN/SG II & S249 & NN/SG II & S249 & NN/SG II & S249 & NN/SG II & S249 \\
\hline Evalutor-1 & 5.67 & 6.00 & 5.33 & 5.67 & 6.33 & 5.33 & 5.33 & 5.00 & 6.67 & 6.00 \\
Evalutor-2 & 4.67 & 5.33 & 4.67 & 5.00 & 5.67 & 5.33 & 6.33 & 5.67 & 7.00 & 5.67 \\
Evalutor-3 & 4.67 & 5.33 & 5.67 & 5.67 & 6.33 & 5.33 & 6.33 & 6.67 & 6.33 & 6.67 \\
Evalutor-4 & 5.00 & 5.67 & 4.67 & 5.33 & 6.00 & 5.67 & 5.33 & 5.33 & 6.67 & 5.67 \\
Evalutor-5 & 4.33 & 4.67 & 5.67 & 5.00 & 5.33 & 5.67 & 6.00 & 6.00 & 5.67 & 5.33 \\
Evalutor-6 & 5.67 & 4.67 & 5.33 & 4.67 & 6.00 & 6.00 & 5.67 & 5.33 & 5.67 & 5.67 \\
Evalutor-7 & 3.67 & 5.00 & 5.33 & 6.00 & 6.00 & 5.67 & 6.67 & 5.67 & 6.67 & 6.00 \\
Evalutor-8 & 4.33 & 5.33 & 5.33 & 5.67 & 6.33 & 5.00 & 7.00 & 6.00 & 7.00 & 6.33 \\
Evalutor-9 & 5.33 & 5.67 & 5.67 & 4.33 & 5.33 & 5.67 & 6.00 & 5.33 & 6.67 & 6.00 \\
Evalutor-10 & 5.00 & 5.67 & 4.67 & 52.67 & 5.33 & 5.00 & 6.33 & 6.00 & 6.33 & 6.67 \\
Total- & 48.34 & 53.34 & 52.34 & 51.34 & 58.65 & 54.67 & 60.99 & 57.00 & 64.86 & 60.01 \\
\hline
\end{tabular}

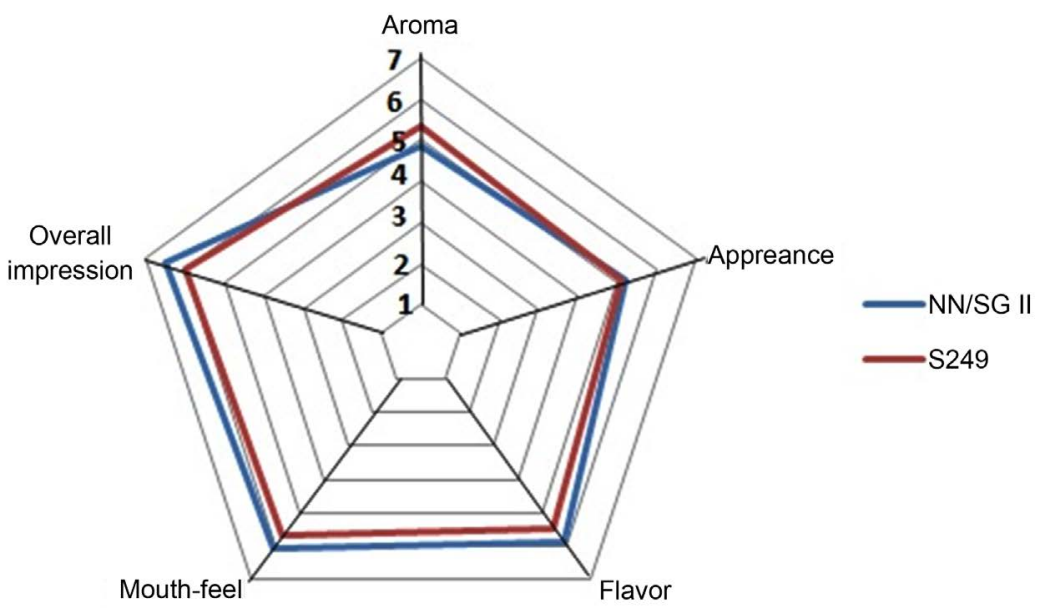

Figure 5. Comparism of the sensory evolution was between NN/SG and S249 strain.

strain which might be due to higher protein content. The color of Gora was slight misty then the industrial strain beer may be due to due to the presence of more phenolic compound in the beer [44]. Gora had slightly scored better than the industrial strain beer in respect of mouth-feel. The overall impression was the final opinion from the assessors, and the Gora was found as drinkable and they may prefer to drink more than one glass. Similar finding were also reported by the previous studies on rice beer sensory analysis [45] [46].

\section{Conclusion}

The traditional fermented rice beer plays an integral role in the ethnic community throughout the world since the beginning of mankind. It is believed that, in the beginning time beer was consumed as medicine but with the progress of time. It has become a product of pleasure and enjoyment. It has a great medicinal and 
therapeutic value [12]. The selection of yeast species is the most vital for production and improving good quality of beer with low PAD activity [47]. The study reveals that the rice beer (gora) produced in Tripura has a significant nutritional value and diversity in terms of quality. In the present study, we isolated, identified and characterized an indigenous yeast strain Pichia kudriavzevii NN/SG II from the rice beer "Gora". The comparative study with industrial strain revealed that the isolated strain can produce higher quality beer in respect of taste, nutritional requirements than industrial strain as per the result depicted in (Table 4, Table 5). This strain can be easily grown in normal temperature with minimum growth requirements. The Koloi tribes of Tripura are producing this indigenous rice beer since long time under household condition with lack of in-depth scientific input and quality standard, a reorientation with scientific input for better results towards manufacturing and increasing shelf-life is very much essential. However, most of the countries of the world have their own traditional staple drink produced in commercial level also. In terms of that this may be a good option to produce our own traditional drink, because there is an immense scope to validate the beneficial properties of this type of traditional beverages through simple scientific techniques with regulations for the sustainable livelihood of the rural people.

\section{Acknowledgements}

We are very much thankful to-Biotech Hubof Mizoram University, Mizoram, India for providing their facility.

\section{Nucleotide Sequence Accession Number}

The sequences of the ITS rDNA region and the isolated yeast strain reported in this study have been deposited in the GenBank nucleotide sequence databases under Accession No. MG388336.

\section{Conflicts of Interest}

The authors have not declared any conflict of interests.

\section{References}

[1] Alan, R.E. (1997) Guidelines for Environmental Assessments and Traditional Knowledge. A Report from the Centre for Traditional Knowledge to the World Council of Indigenous People. Environment Canada, Canada.

[2] Kurtzman, C.P. and Fell, J.W. (1998) Summary of Species Characteristics. In: The Yeasts a Taxonomic Study, 4th Edition, Elsevier, Amsterdam.

[3] Bhattacharjee, P.N. (2002) Lokabritter Aloke Koloi Sampraday-The Koloi in the Light of Peoples History. 2nd Edition, Tribal Research Institute, Parul Prakashani.

[4] Primarycencus Report. http://www.censusindia.gov.in/2011census/population_enumeration.html

[5] Deori, C., Bengum, S.S. and Mao, A.A. (2007) Ethnobotany of Sujen, a Local Rice Beer of Deori Tribe of Assam. Indian Journal of Traditional Knowledge, 6, 121-125. 
[6] Samati, H. and Begum, S.S. (2007) Kiad, a Popular Local Liquor of Pnar Tribe of Jainti Hills District, Meghalaya. Indian Journal of Traditional Knowledge, 6, 133-135.

[7] Jeyaram, K., Singh, W.M., Capece, A. and Romano, P. (2008) Molecular Identification of Yeast Species Associated with "Hamei"-A Traditional Starter Used for Rice Wine Production in Manipur. International Journal of Food Microbiology, 124, 115-125. https://doi.org/10.1016/j.ijfoodmicro.2008.02.029

[8] Tamang, B. and Tamang, J.P. (2007) Role of Lactic Acid Bacteria and Their Functional Properties in Goyang, a Fermented Leafy Vegetable Product of the Sherpas. Journal of Hill Research, 20, 53-61.

[9] Tamang, J.P., Tamang, N., Thapa, S., Dewan, S., Tamang, B., Yonzan, H., Rai, A.K., Chettri, R., Chakrabarty, J. and Kharel, N. (2012) Microorganisms and Nutritional Value of Ethnic Fermented Foods and Alcoholic Beverages of North-East India. Indian Journal of Traditional Knowledge, 11, 7-25.

[10] Sekar, S. and Mariappan, S. (2007) Usage of Traditional Fermented Products by Indian Rural Folks and IPR. Indian Journal of Traditional Knowledge, 6, 111-120.

[11] Lee, C.H. (2009) Food Biotechnology. In: Campbell-Platt, G., Eds., Food Science and Technology, John Wiley and Sons, New York, 85-95.

[12] Ghosh, S., Rahaman, L., Kaipeng, D.L., Deb, D., Nath, N., Tribedi, P. and Sharma, B.K. (2016) Community-Wise Evaluation of Rice Beer Prepared by Some Ethnic Tribes of Tripura. Journal of Ethnic Foods, 3, 251-256. https://doi.org/10.1016/j.jef.2016.12.001

[13] Dewan, S. and Tamang, J.P. (2007) Dominant Lactic Acid Bacteria and Their Technological Properties Isolated from the Himalayan Ethnic Fermented Milk Products. Antonie Van Leeuwenhoek, 92, 343-352. https://doi.org/10.1007/s10482-007-9163-5

[14] Kurtzman, C.P., Fell, J.W., Boekhout, T. and Robert, V. (2011) Methods for isolation phenotypic characterization and maintenance of yeasts. In: Kurtzman, C.P., Fell, J.W. and Boekhout, T., Eds., The Yeasts a Taxonomic Study, 5th Edition, Elsevier, Amsterdam, Netherlands. https://doi.org/10.1016/B978-0-444-52149-1.00007-0

[15] Cenis, J.L. (1992) Rapid Extraction of Fungal DNA for PCR Amplification. Nucleic Acids Research, 20, 2380. https://doi.org/10.1093/nar/20.9.2380

[16] White, T.J., Bruns, T., Lee, S. and Taylor, J. (1990) Amplification and Direct Sequencing of Fungal Ribosomal RNA Genes for Phylogenetics. In: PCR Protocols: $A$ Guide to Methods and Applications, Academic Press, San Diego, 315-322. https://doi.org/10.1016/B978-0-12-372180-8.50042-1

[17] Altschul, S.F., Madden, T.L., Schaffer, A.A., Zhang, J., Zhang, Z., Miller, W. and Lipman, D.J. (1997) Gapped BLAST and PSI-BLAST: A New Generation of Protein Database Search Programs. Nucleic Acids Research, 25, 3389-3402. https://doi.org/10.1093/nar/25.17.3389

[18] Saitou, N. and Nei, M. (1987) The Neighbor-Joining Method: A New Method for Reconstructing-Phylogenetic Trees. Molecular Biology and Evolution, 4, 406-425.

[19] Felsenstein, J. (1985) Phylogenies and the Comparative Method. The American Naturalist, 126, 1-25. https://doi.org/10.1086/284325

[20] Tamura, K. (1992) Estimation of the Number of Nucleotide Substitutions When There Are Strong Transition-Transversion and G+C-Content Biases. Molecular Biology and Evolution, 9, 678-687.

[21] Tamura, K., Stecher, G., Peterson, D., Kumar, S. and Filipski, A. (2013) MEGA6: 
Molecular Evolutionary Genetics Analysis Version 6.0. Molecular Biology and EvoIution, 30, 2725-2729. https://doi.org/10.1093/molbev/mst197

[22] Basumatary, T.K., Basumatary, R.T., Medhi, S., Bose, S. and Begum, R.S. (2014) Biochemical Analysis of Jou: A Traditional Drink of the Boro Tribe of Assam and North East India. IOSR Journal of Environmental Science, Toxicology and Food Technology, 8, 99-103. https://doi.org/10.9790/2402-087199103

[23] Albalasmeh, A.A., Berhe, A.A. and Ghezzehei, T.A. (2013) A New Method for Rapid Determination of Carbohydrate and Total Carbon Concentrations Using UV Spectrophotometry. Carbohydrate Polymers, 97, 253-261. https://doi.org/10.1016/j.carbpol.2013.04.072

[24] Sapan, C.V., Lundblad, R.L. and Price, N.C. (1998) Colorimetric Protein Assay Techniques. Biotechnology and Applied Biochemistry, 29, 99-108.

[25] Ugliano, M., Bartowsky, E.J., McCarthy, J., Moio, L. and Henschke, P.A. (2006) Hydrolysis and Transformation of Grape Glycosidically Bound Volatile Compounds during Fermentation with Three Saccharomyces Yeast Strains. Journal of Agricultural and Food Chemistry, 54, 6322-6331. https://doi.org/10.1021/jf0607718

[26] Wang, M.L., Choong, Y.M., Su, N.W. and Lee, M.H. (2003) A Rapid Method for Determination of Ethanol in Alcoholic Beverages Using Capillary Gas Chromatography. Journal of Food and Drug Analysis, 11, 133-140.

[27] ISO 8586-1 (2012) Sensory Analysis. General Guidance for the Selection, Training and Monitoring of Assessors. Part 1: Selected Assessors. International Organization for Standardization, Geneva, Switzerland.

[28] Blanco, C.A., Nimubona, D., Fernandez, E.F. and Alvarez, I. (2015) Sensory Characterization of Commercial Lager Beers and Their Correlations with ISO- $\alpha$-Acid Concentrations. Journal of Food and Nutrition Research, 3, 1-8. https://doi.org/10.12691/jfnr-3-1-1

[29] Kabir, M.H., Hasan, N., Rahman, M.M., Rahman, M.A., Khan, J.A., Hoque, N.T., Bhuiyan, M.R.D., Jahan, M.R. and Rahmatullah, M. (2014) A Survey of Medicinal Plants Used by the Debbarma Clan of the Tripura Tribe of Moulvibazar District, Bangladesh. Journal of Ethnobiology and Ethnomedicine, 10, 19. https://doi.org/10.1186/1746-4269-10-19

[30] Praveena, R.J. and Estherlydia, D. (2014) Comparative Study of Phytochemical Screening and Anti-Oxidant Capacity of Vinegar Made from Peel and Fruit of Pineapple (Ananas comosus L.). International Journal of Pharma and Bio Sciences, $\mathbf{5}$, 394-403.

[31] Ali, S., El-Ahmadhy, S., Ayuob, N. and Singab, A.N. (2015) Phytochemicals of Markhamia Species (Bignoniaceae) and Their Therapeutic Value: A Review. European Journal of Medicinal Plants, 6, 124-142. https://doi.org/10.9734/EJMP/2015/15015

[32] Deka, D. and Sarma, G.C. (2010) Traditionally Used Herbs in the Preparation of Rice-Beer by the Abha Tribe of Goalpara District, Assam. Indian Journal of Traditional Knowledge, 9, 459-462.

[33] Choudhury, D., Ghosal, M., Das, A.P. and Mandal, P. (2013) In Vitro Antioxidant Activity of Methanolic Leaves and Barks Extracts of Four Litsea Plants. Asian Journal of Plant Science \& Research, 3, 99-107.

[34] N'guessan, K.F., Brou, K., Jacques, N., Casaregola, S. and Dje, K.M. (2011) Identification of Yeasts during Alcoholic Fermentation of Tchapalo, a Traditional Sorghum Beer from Côte D’Ivoire. Antonie van Leeuwenhoek, 99, 855-864. https://doi.org/10.1007/s10482-011-9560-7

[35] Koutinas, M., Patsalou, M., Stavrinou, S. and Vyrides, I. (2015) High Temperature 
Alcoholic Fermentation of Orange Peel by the Newly Isolated Thermotolerant $P i$ chia kudriavzevii KVMP10. Letters in Applied Microbiology, 62, 75-83. https://doi.org/10.1111/lam.12514

[36] Albers, E., Larsson, C., Lide, N.G., Niklasson. C. and Gustafsson, L. (1996) Influence of the Nitrogen Source on Saccharomyces cerevisiae Anaerobic Growth and Product Formation. Applied and Environmental Microbiology, 62, 3187-3195.

[37] Fleet, G.H. (2003) Yeast Interactions and Wine Flavor. International Journal of Food Microbiology, 86, 11-22. https://doi.org/10.1016/S0168-1605(03)00245-9

[38] Neilsen, S.S. (2010) Food Analysis Laboratory Manual. 2nd Edition, Springer, New York. https://doi.org/10.1007/978-1-4419-1463-7

[39] Casida, L.E. (2005) Industrial Microbiology. New Age, New Delhi, 258-259.

[40] Mensah, P. (1997) Fermentation-The Key to Food Safety Assurance in Africa? Food Control, 8, 271-278. https://doi.org/10.1016/S0956-7135(97)00020-0

[41] Muyanja, B.K., Narvhus, J.A., Treimo, J. and Langsrud, T. (2004) Isolation, Characterization and Identification of Lactic Acid Bacteria from Bushera: A Ugandan Traditional Fermented Beverage. International Journal of Food Microbiology, 80, 201-210. https://doi.org/10.1016/S0168-1605(02)00148-4

[42] Stanbury, P.F., Whitaker, A. and Hall, S.J. (1997) Principles of Fermentation Technology. Aditya Books Ltd., New Delhi.

[43] Rabin, D., and Forget, C. (1998) The Dictionary of Beer and Brewing. 2nd Edition, Fitzroy Dearborn Publishers, Chicago, IL.

[44] Phiarais, B., Mauch, A., Schehl, B., Zarnkow, M., Gastl, M., Herrmann, M., Zannini, E. and Arendt, E. (2010) Processing of a Top Fermented Beer Brewed from 100\% Buckwheat Malt with Sensory and Analytical Characterization. Journal of the Institute of Brewing, 116, 265-274. https://doi.org/10.1002/j.2050-0416.2010.tb00430.x

[45] Chollet, S., Valentin, D. and Abdi, H. (2005) Do Trained Assessors Generalize Their Knowledge to New Stimuli? Food Quality and Preference, 16, 13-23. https://doi.org/10.1016/j.foodqual.2003.12.003

[46] Clapperton, J.F. and Piggot, J.R. (1979) Differentiation of Ale and Lager Flavor by Principal Component Analysis of Flavor Characterization Data. Journal of the Institute of Brewing, 85, 271-274. https://doi.org/10.1002/j.2050-0416.1979.tb03921.x

[47] Lentz, M. (2018) The Impact of Simple Phenolic Compounds on Beer Aroma and Flavor. Fermentation, 4, 20. https://doi.org/10.3390/fermentation4010020 